\title{
Oxidation Reactions of Ethane over Ba-Ce-O Based Perovskites
}

James E. Miller, Allen G. Sault, Daniel E. Trudell, Tina M. Nenoff, Steven G. Thoma, Nancy B. Jackson

Sandia National Laboratories, Albuquerque, NM 87185-0710

\begin{abstract}
Ethane oxidation reactions were studied over pure and $\mathrm{Ca}-, \mathrm{Mg}-, \mathrm{Sr}-, \mathrm{La}-, \mathrm{Nd}-$, and $\mathrm{Y}$-substituted $\mathrm{BaCeO}_{3}$ perovskites under oxygen limited conditions. Several of the materials, notably the $\mathrm{Ca}$ - and $\mathrm{Y}$-substituted materials, show activity for complete oxidation of the hydrocarbon to $\mathrm{CO}_{2}$ at temperatures below $650^{\circ} \mathrm{C}$. At higher temperatures, the oxidative dehydrogenation $(\mathrm{ODH})$ to ethylene becomes significant.
\end{abstract} Conversions and ethylene yields are enhanced by the perovskites above the thermal reaction in our system in some cases. The perovskite structure is not retained in the high temperature reaction environment. Rather, a mixture of carbonates and oxides is formed. Loss of the perovskite structure correlates with a loss of activity and selectivity to ethylene.

\section{Introduction}

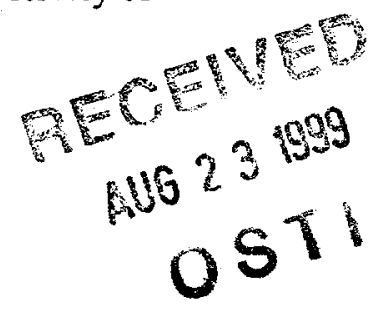

Perovskite oxides of the general formula $\mathrm{ABO}_{3}$ are of broad interest as catalysts for oxidation reactions because of their ability to conduct oxygen and to support significant variations in oxygen content. They are known to catalyze a number of oxidation 


\section{DISCLAIMER}

This report was prepared as an account of work sponsored by an agency of the United States Government. Neither the United States Government nor any agency thereof, nor any of their employees, make any warranty, express or implied, or assumes any legal liability or responsibility for the accuracy, completeness, or usefulness of any information, apparatus, product, or process disclosed, or represents that its use would not infringe privately owned rights. Reference herein to any specific commercial product, process, or service by trade name, trademark, manufacturer, or otherwise does not necessarily constitute or imply its endorsement, recommendation, or favoring by the United States Government or any agency thereof. The views and opinions of authors expressed herein do not necessarily state or reflect those of the United States Government or any agency thereof. 


\section{DISCLAIMER}

Portions of this document may be illegible in electronic image products. Images are produced from the best available original document. 
reactions including the oxidation of light hydrocarbons to $\mathrm{CO}_{2}$ and $\mathrm{H}_{2} \mathrm{O}$ (combustion), oxidative coupling of methane (OCM), and oxidative dehydrogenation (ODH). $\mathrm{LaCoO}_{3}$ was first proposed as a combustion catalyst for automobile exhaust in 1971 [1]. Since that time a number of studies have been conducted on perovskites as combustion catalysts and several materials have been reported to be as effective as supported $\mathrm{Pt}$. Most of the effective systems reported are formulated with lanthanum on A sites and a transition metal ( $\mathrm{Co}, \mathrm{Mn}, \mathrm{Fe}, \mathrm{Ni})$ on the $\mathrm{B}$ sites. Additional elements are substituted to optimize the catalytic properties. Common substitutions include $\mathrm{Ca}, \mathrm{Ba}, \mathrm{Sr}$ and $\mathrm{Ce}$ for La, and a second transition metal substituted for the first. An example of such a material reported to be effective for $\mathrm{n}$-butane combustion is $\left(\mathrm{La}_{0.2} \mathrm{Sr}_{0.8}\right)\left(\mathrm{Co}_{0.6} \mathrm{Fe}_{0.4}\right) \mathrm{O}_{3}[2]$.

Perovskite catalysts reported for the OCM reaction are reflective of the basic oxides most often reported to catalyze this reaction. Hence, they are typically composed of an alkaline earth and/or rare earths coupled with a metal or transition metal. Some examples include $\mathrm{Ba}\left(\mathrm{Co}_{1-y} \mathrm{Fe}_{y}\right) \mathrm{O}_{3-\delta}[3],\left(\mathrm{La}_{1-x} \mathrm{Ba}_{x}\right)\left(\mathrm{Co}_{1-\mathrm{y}} \mathrm{Fe}_{y}\right) \mathrm{O}_{3-\delta}[3], \mathrm{Sr}\left(\mathrm{Co}_{1-y} \mathrm{Fe}_{y}\right) \mathrm{O}_{3-\delta}[3]$, $\mathrm{BaCeO}_{3}[4], \mathrm{BaPbO}_{3}[5,6], \mathrm{Ba}\left(\mathrm{Pb}_{1-\mathrm{y}} \mathrm{Bi}_{\mathrm{y}}\right) \mathrm{O}_{3-\delta}[5], \mathrm{BaBiO}_{3}[6], \mathrm{BaSnO}_{3}[6]$, $\left(\mathrm{Ca}_{1-\mathrm{x}} \mathrm{Sr}_{\mathrm{x}}\right)\left(\mathrm{Ti}_{1-\mathrm{y}} \mathrm{Fe}_{\mathrm{y}}\right) \mathrm{O}_{3-\delta}[7],\left(\mathrm{Ca}_{1-\mathrm{x}} \mathrm{Sr}_{\mathrm{x}}\right)\left(\mathrm{Ti}_{1-\mathrm{y}} \mathrm{Co}_{\mathrm{y}}\right) \mathrm{O}_{3-\delta}[7], \mathrm{SrCeO}_{3}$ [4], and $\mathrm{Sr}\left(\mathrm{Ce}_{1-\mathrm{y}} \mathrm{Yb}_{\mathrm{y}}\right) \mathrm{O}_{3-\delta}$ [8]. Only a few studies of ODH over perovskites have been conducted. Perovskite materials that have been studied for this reaction include $\operatorname{Sr}\left(\mathrm{Ce}_{1-y} \mathrm{Yb}_{y}\right) \mathrm{O}_{3-\delta}[9]$, $\mathrm{Ca}\left(\mathrm{Ti}_{1-y} \mathrm{Fe}_{\mathrm{y}}\right) \mathrm{O}_{3-\delta}[10], \operatorname{Sr}\left(\mathrm{Ti}_{1-y} \mathrm{Fe}_{\mathrm{y}}\right) \mathrm{O}_{3-\delta}[10]$, and $\left(\mathrm{La}_{1-x} \mathrm{Sr}_{\mathrm{x}}\right) \mathrm{FeO}_{3-\delta}[11]$. Note that the $(\mathrm{CaSr})(\mathrm{FeTi}) \mathrm{O}$ and the $\mathrm{Sr}(\mathrm{CeYb}) \mathrm{O}$ systems have been reported to catalyze both the OCM and ODH reactions. In fact, the authors of these studies have pointed out potential similarities between the OCM and ODH reactions. For example, in the OCM reaction, 
ethylene may be formed through secondary reactions of the ethane product. In studies comparing OCM and $\mathrm{ODH}$ over rare earth oxides, it was found that the reaction of ethane is significantly faster and more selective than the reaction of methane $[12,13]$. Further, $p$ type conductivity has been correlated with catalyst activity for both the OCM and $\mathrm{ODH}$ reactions $[7,10,11,14]$.

In this study, we have surveyed the oxidation reactions of ethane over crystalline perovskite catalysts with the general formulas $\mathrm{BaCeO}_{3}, \mathrm{Ba}\left(\mathrm{Ce}_{1-\mathrm{y}} \mathrm{M}_{\mathrm{y}}\right) \mathrm{O}_{3-\delta}$, and $\left(\mathrm{Ba}_{1-\mathrm{x}} \mathrm{M}_{\mathrm{x}}\right) \mathrm{CeO}_{3-\delta .} . \mathrm{BaCeO}_{3}$ has been reported to catalyze the $\mathrm{OCM}$ reaction at $750^{\circ} \mathrm{C}$ [4], and the material is known to exhibit at least partial hole conduction when the Ce sites are partially substituted with lower valent metals such as $\mathrm{La}, \mathrm{Nd}, \mathrm{Ca}$, or $\mathrm{Y}[15,16]$. Thus, by analogy with the $(\mathrm{CaSr})(\mathrm{FeTi}) \mathrm{O}$ and the $\mathrm{Sr}(\mathrm{CeYb}) \mathrm{O}$ systems, we anticipated that the $\mathrm{Ba}-\mathrm{Ce}-\mathrm{O}$ perovskite system might catalyze the $\mathrm{ODH}$ reaction of ethane, at least at high temperatures [17]. In fact, we did observe that several of the materials led to enhanced conversion of ethane and higher yields of ethylene when compared to the high temperature thermal (homogeneous) reaction in our system.

\section{Experimental}

$\mathrm{BaCeO}_{3}$ and $\mathrm{Ba}\left(\mathrm{Ce}_{1-\mathrm{y}} \mathrm{M}_{\mathrm{y}}\right) \mathrm{O}_{3-\delta},(\mathrm{M}=\mathrm{La}, \mathrm{Y}, \mathrm{Nd}, \mathrm{Ca} ; \mathrm{y}=0.05-0.2)$ were made through a solid state synthesis from $\mathrm{BaCO}_{3}, \mathrm{CeO}_{2}, \mathrm{La}_{2} \mathrm{O}_{3}, \mathrm{Y}_{2} \mathrm{O}_{3}, \mathrm{Nd}_{2} \mathrm{O}_{3}$, and $\mathrm{CaCO}_{3}$ (all at least 99.99\% pure from Sigma Chemicals). The starting materials were dry mixed in the desired stoichiometry for three hours in an agate ball mill. The mixtures were then transferred to platinum crucibles and heated $\left(300^{\circ} \mathrm{C} / \mathrm{hr}\right.$ ramp rate) in air to $1250^{\circ} \mathrm{C}$ and 
held for 5 hrs. The samples were then once again dry milled, and fired as before. Samples of $\mathrm{BaCeO}_{3}, \mathrm{BaCe}_{08} \mathrm{Ca}_{0.2} \mathrm{O}_{2.8}$, and $\left(\mathrm{Ba}_{0.8} \mathrm{M}_{0.2}\right) \mathrm{CeO}_{3},(\mathrm{M}=\mathrm{Mg}, \mathrm{Ca}, \mathrm{Sr} ; \mathrm{Mg}$ from $\mathrm{MgO}$ and $\mathrm{Sr}$ from $\mathrm{SrCO}_{3}$ ) and were made in a similar fashion, except that the materials were pressed into pellets and granulated to $-40 /+60$ mesh prior to the second firing.

The crystalline phases present in the catalysts were determined prior-to and after reaction testing by powder X-ray diffraction. Data were collected at room-temperature on a Siemens Model D500 automated diffractometer, using $\theta 2 \theta$ sample geometry and $\mathrm{Cu} \mathrm{K}_{\alpha}$ radiation, between $2 \theta=5$ and $60^{\circ}$ with a step size $0.05^{\circ}$. Thermogravimetric analyses (TGA) were performed using a TA Instruments 2000 thermal analysis system interfaced to a TA instruments TGA cell. Samples (nominally $20 \mathrm{mg}$ in size) were heated from room temperature to $950^{\circ} \mathrm{C}$ in atmospheres of air or $\mathrm{CO}_{2}$ at a rate of $10^{\circ} \mathrm{C} / \mathrm{min}$.

The catalysts were tested for oxidation reactions of ethane in a conventional stainless steel flow system operating near atmospheric pressure. The feed, consisting of $17 \mathrm{~mol} \%$ $\mathrm{C}_{2} \mathrm{H}_{6}, 8.5 \mathrm{~mol} \% \mathrm{O}_{2}$ (a stoichiometric $\mathrm{C}_{2} \mathrm{H}_{6} / \mathrm{O}_{2}$ ratio for the $\mathrm{ODH}$ to ethylene), and the balance $\mathrm{N}_{2}$, was passed over $0.25 \mathrm{~g}$ of catalyst. The catalyst was held in place between plugs of quartz wool and supported by a $3.2 \mathrm{~mm}$ O.D. 316 stainless steel tube placed inside the $4.9 \mathrm{~mm}$ I.D. 316 stainless steel reactor tube. Reaction temperatures were measured with a thermocouple positioned inside the reactor tube just above the catalyst. For the powders, single samples were tested at temperatures starting at $350^{\circ} \mathrm{C}$ and increasing in intervals to $750^{\circ} \mathrm{C}$. Separate granular samples were tested at temperatures of 500,600 and $700{ }^{\circ} \mathrm{C}$. Granular samples of $\mathrm{BaCeO}_{3}$ were also tested at 625 and 650 
${ }^{\circ} \mathrm{C}$. Reactants and products were analyzed with an on-line MTI gas chromatograph utilizing a $10 \mathrm{~m}$ molecular sieve 5A PLOT column $\left(\mathrm{O}_{2}, \mathrm{CH}_{4}, \mathrm{CO}\right)$ and a $8 \mathrm{~m}$ Poraplot Q column $\left(\mathrm{CO}_{2}, \mathrm{C}_{2} \mathrm{H}_{4}, \mathrm{C}_{2} \mathrm{H}_{6}, \mathrm{C}_{3} \mathrm{H}_{6}, \mathrm{C}_{3} \mathrm{H}_{8}\right)$. A condenser positioned downstream of the reactor removed excess water prior to the analysis. Due to the small amount of product water and condenser inefficiency, accurate quantification of the water was not possible. Control experiments were conducted in a reactor tube containing only a thermocouple and a quartz wool plug resting on the $3.2 \mathrm{~mm}$ support tube to determine the thermal (noncatalytic) behavior of the system.

X-ray Photoelectron Spectroscopy (XPS) studies were conducted in a combined ultrahigh vacuum (UHV) surface analysis/atmospheric pressure reactor system $[18,19]$ that allows measurement of the surface properties of catalytic materials before and after exposure to reactive environments without intervening exposure to air. With this system, $\mathrm{BaCeO}_{3}$, and $\mathrm{Mg}$ - and $\mathrm{Ca}-$ modified $\mathrm{BaCeO}_{3}$ (crushed granules) were analyzed following treatment in reactive environments to simulate reaction conditions. The treatments were designed to simulate increasing conversion of ethane and consumption of oxygen with increasing reaction temperature. Thus, the conditions studied included treatment in a stoichiometric (for ODH) reaction mixture of 108 Torr ethane and 54 Torr oxygen at $500^{\circ} \mathrm{C}$ for $1 \mathrm{hr}$, treatment in an ethane rich mixture of 108 Torr ethane and 10 Torr oxygen at $600^{\circ} \mathrm{C}$ for $1 \mathrm{hr}$, treatment in $108 \mathrm{Torr}$ ethane at $700^{\circ} \mathrm{C}$ for $1 \mathrm{hr}$, and treatment in 108 Torr ethane and 54 Torr $\mathrm{CO}_{2}$ at $700^{\circ} \mathrm{C}$ for $1 \mathrm{hr}$. Prior to all treatments the samples were outgassed in vacuum for five mins at the desired reaction temperature to remove any volatile organic species. $\mathrm{XP}$ spectra were taken following each treatment using a 
non-monochromatic $\mathrm{Mg} \mathrm{K} \alpha$ source with an analyzer resolution of $1.0 \mathrm{eV}$. Because of the insulating nature of the perovskites, some sample charging always occurred and binding energies were referenced to the $\mathrm{Ba} 3 \mathrm{~d}_{5 / 2}$ peak at $779.7 \mathrm{eV}[20,21]$. Spectra were collected in the $\mathrm{Ba} 3 \mathrm{~d}, \mathrm{Ce} 3 \mathrm{~d}, \mathrm{O} 1 \mathrm{~s}$, and $\mathrm{C} 1 \mathrm{~s}$ regions for each sample, as well as the $\mathrm{Ca} 2 \mathrm{p}$ or $\mathrm{Mg}$ $2 p$ regions for samples containing these modifiers. All peaks were subjected to Tougaard background subtraction followed by integration of peak areas to determine relative XPS signal intensities.

\section{Results and Discussion}

\section{Reaction testing and characterization}

$\mathrm{BaCeO}_{3}$ and materials consisting of $\mathrm{Ba}\left(\mathrm{Ce}_{1-\mathrm{y}} \mathrm{M}_{\mathrm{y}}\right) \mathrm{O}_{3-\delta}(\mathrm{M}=\mathrm{Ca}, \mathrm{La}, \mathrm{Y}, \mathrm{Nd} ; \mathrm{x}=0.05,0.10$, $0.15,0.20$ ) were tested for the $\mathrm{ODH}$ of ethane in the powder form. Prior to testing, XRD analysis showed the materials to be a single tetragonal phase [22] indicating that the substitutions did occur on the $\mathrm{B}$ sites. The reaction data for the perovskite powders can generally be divided into a low temperature regime and high temperature regime, with a transition in reaction chemistry and phase stability occurring between 650 and $750{ }^{\circ} \mathrm{C}$. Below $650{ }^{\circ} \mathrm{C}$ the perovskite phases are stable in the reaction environment and heterogeneous reactions dominate the reactivity. At higher temperatures, the perovskite phases decompose and the homogeneous contribution to the chemistry is significant.

Table 1 summarizes the results in the low temperature regime of the reaction testing over $\mathrm{BaCeO}_{3}$, the $10 \%$ substituted materials, and the thermal control experiments. Carbon and oxygen balances both typically closed within $\pm 5 \%$ with an occasional outlying data 
point. Oxygen balances were calculated assuming all hydrogen in reacted hydrocarbons was converted to water. The data in Table 1 show that each of the perovskite powders enhance ethane conversion compared to the thermal reaction. However the dominant reaction is the nonselective oxidation of the hydrocarbon to $\mathrm{CO}_{2}$, particularly over the $\mathrm{Ca}$ - and $\mathrm{Y}$-substituted samples. Thus, despite higher conversion, ethylene yields are not significantly improved over the noncatalytic thermal yields.

Table 1 is fairly representative of all the samples tested as the results were relatively independent of substitution level over the range studied, with the exception of the Casubstituted samples. For the Ca-substituted materials there appears to be a discernible relationship between the $\mathrm{Ca}$ content and the results of the reaction testing in the low temperature regime. The low temperature results for all the Ca-substituted powders are summarized in Table 2. In general, the ability of the Ca-substituted materials to activate ethane decreases with increasing substitution, while the selectivity to ethylene increases with increasing substitution (for example compare the data at $550^{\circ} \mathrm{C}$ ). Interestingly, the $5 \%$ substituted material is the most different from $\mathrm{BaCeO}_{3}$ while the $20 \%$ substituted material is very similar to $\mathrm{BaCeO}_{3}$.

The transition between the low and high temperature regimes is marked by sharp increases in conversion for both the catalytic and thermal tests. This is consistent with the expected shift from a predominantly heterogeneous reaction mechanism to a predominantly homogeneous reaction mechanism. In all cases tested, the high temperature reaction was oxygen limited ( $>99 \%$ oxygen conversion). Interpretation of 
the data in the high temperature regime was complicated by two factors. First, the oxygen balance calculations systematically indicate that more oxygen was consumed than was fed to the reactor. This is likely due to a breakdown in the assumption that all hydrogen atoms associated with converted ethane produce water. Rather, thermal dehydrogenation/cracking or reforming reactions are consuming $\mathrm{H}$ and are also likely producing $\mathrm{H}_{2}$. This is supported by the appearance of methane and smaller quantities of propane and propylene at temperatures of $700^{\circ} \mathrm{C}$ and higher. The second complication was the fact that the reactor pressures slowly increased, in some cases to twice its initial value, when the perovskite powders were held for extended periods at temperatures greater than $650^{\circ} \mathrm{C}$ due to decomposition and sintering of the fine catalyst powder (see below).

Despite the complicating factors, the high temperature data summarized in Table 3 consistently indicates that the perovskite materials influenced the high temperature chemistry. For example, at $700{ }^{\circ} \mathrm{C}$, the ethylene yield over $\mathrm{Ba}\left(\mathrm{Ce}_{0.9} \mathrm{Ca}_{0.1}\right) \mathrm{O}_{2.9}(34 \%)$ is twice that of the thermal reaction (17\%). However, cycling this material to $750^{\circ} \mathrm{C}$ and then back to $700{ }^{\circ} \mathrm{C}$ reduces the selectivity by over $35 \%$ and the yield by over $50 \%$ (not shown in table). The high yields achieved over $\mathrm{Ba}\left(\mathrm{Ce}_{0.9} \mathrm{Ca}_{0.1}\right) \mathrm{O}_{2.9}$ could not be duplicated by intentionally manipulating the reactor pressure to simulate catalyst sintering effects in a thermal control experiment.

To put the high temperature results in perspective, it is important to note that the highest yields of ethylene over the perovskite powders are at best only slightly better or 
equivalent to thermal results reported in the literature by Burch and Crabb [23] (74\% selectivity for $45 \%$ ethane conversion giving a yield of $33 \%$ at $600{ }^{\circ} \mathrm{C}$ ). It is also interesting to note that although all the reactions in our high temperature studies were oxygen limited, higher ethane conversions were achieved over the majority of the perovskites. Because of the oxygen limitation, these higher conversion were likely achieved by following reaction pathways requiring less or no oxygen, for example by producing $\mathrm{CO}$ rather than $\mathrm{CO}_{2}$, or by producing $\mathrm{H}_{2}$ rather than $\mathrm{H}_{2} \mathrm{O}$. These reaction schemes would allow the higher yields over the Ca-substituted materials compared to the thermal reaction, despite the similarities in selectivity to ethylene.

Following the reaction tests, the catalysts were recovered from the reactors for analysis. Each sample of the fine powders tested had converted to a single hard pellet-like form, accounting for the increased reactor pressures. X-ray diffraction analysis of the recovered catalysts showed that the perovskites had significantly decomposed during the tests, and that new phases, principally $\mathrm{BaCO}_{3}$ and $\mathrm{CeO}_{2}$ were formed. The conversion to carbonates was confirmed by TGA analysis performed on powder samples of $\mathrm{BaCeO}_{3}$ and $\mathrm{Ba}\left(\mathrm{Ce}_{0.9} \mathrm{Ca}_{0.1}\right) \mathrm{O}_{2.9}$ in a flowing $\mathrm{CO}_{2}$ atmosphere. Both materials began to show a weight gain at $500^{\circ} \mathrm{C}$ that continued to increase throughout the remainder of the temperature ramp to $950^{\circ} \mathrm{C}$. The total weight gain through the course of the temperature ramp was $7-9 \%$ and was still increasing when the experiments were terminated.

Complete conversion of $\mathrm{BaCeO}_{3}$ to $\mathrm{BaCO}_{3}$ and $\mathrm{CeO}_{2}$ would result in about a $14 \%$ weight increase. Both materials exhibited stable weights when heated in an air environment to $950{ }^{\circ} \mathrm{C}$. Hence the catalysts are unstable and reactive with high $\mathrm{CO}_{2}$ concentrations, at 
least at elevated temperatures. A related observation is the fact that the catalysts have a limited "shelf-life" when stored in an environment accessible to the atmosphere. Duplicate experiments with the same batch of Ca-substituted catalysts showed a decreasing $700^{\circ} \mathrm{C}$ ethylene selectivity over time (several weeks to months). This may be due to a slow reaction of the basic perovskite surface with atmospheric $\mathrm{CO}_{2}$.

In order to gain further insight into the high temperature regime and catalyst phase transitions, granular forms of $\mathrm{BaCeO}_{3}, \mathrm{Ba}\left(\mathrm{Ce}_{0.8} \mathrm{Ca}_{0.2}\right) \mathrm{O}_{2.8}$ and $\left(\mathrm{Ba}_{0.8} \mathrm{Ca}_{0.2}\right) \mathrm{CeO}_{3}$ were tested at temperatures of 500,600 and $700{ }^{\circ} \mathrm{C}$ (also 625 and $650^{\circ} \mathrm{C}$ for $\mathrm{BaCeO}_{3}$ ). Granules of $\left(\mathrm{Ba}_{0.8} \mathrm{Mg}_{0.2}\right) \mathrm{CeO}_{3}$ and $\left(\mathrm{Ba}_{0.8} \mathrm{Sr}_{0.2}\right) \mathrm{CeO}_{3}$ were also tested. The catalysts were brought to temperature in the flowing reaction mixture, and the activity was monitored over several hours time. After the tests, the catalysts were cooled to room temperature in the reaction mixture and recovered for analysis. In all cases the reactor pressure remained constant at about 17 psia during the tests of the granular materials.

The granular materials behave somewhat differently than their fine powder counterparts (Figure 1). Most notably, little differentiation in behavior is observed between the different compositions of the granular catalysts. The large number of data points in Figure 1 results from changes in the catalysts as a function of time. The figure shows that perovskite granules are neither effective combustion or $\mathrm{ODH}$ catalysts under the conditions studied. In every case, there is some ethylene produced, yet the thermal reaction gives higher ethylene selectivities (and hence higher yields) at any given conversion. The granular $\mathrm{BaCeO}_{3}$ and $\mathrm{Ba}\left(\mathrm{Ce}_{0.8} \mathrm{Ca}_{0.2}\right) \mathrm{O}_{2.8}$ catalysts show lower 
conversions that the corresponding powders, but higher selectivities to ethylene at 500 and $600^{\circ} \mathrm{C}$. This is probably related to the smaller surface areas of the granular catalysts (compared to the powders) providing a reaction environment more like the thermal runs. At $700^{\circ} \mathrm{C}$, the data show signs of catalyst instability. The yield (and selectivity) of ethylene just after the reactor stabilizes at $700{ }^{\circ} \mathrm{C}$ is consistently much higher than that 15 mins into the reaction. After $15 \mathrm{~min}$, the conversions are much reduced compared to the powder data, apparently due to reduced selectivity to ethylene as the reactions were oxygen limited. XRD analysis of the recovered granular samples show no changes in the materials tested at 500 or $600^{\circ} \mathrm{C}$ (or $650^{\circ} \mathrm{C}$ for $\mathrm{BaCeO}_{3}$ ). At $700^{\circ} \mathrm{C}$, there is clearly a break down of the original perovskite phase. The resultant phases are a combination of $\mathrm{BaCO}_{3}, \mathrm{CeO}_{2}$, and possibly $\mathrm{Ce}_{1-\mathrm{x}} \mathrm{M}_{\mathrm{x}} \mathrm{O}_{2-0.5 \mathrm{x}}$ (a cubic fluorite structure). The peak widths are broad for all phases indicating either small crystallite sizes, or poorly ordered lattice structures. This data in conjunction with the fine powder data suggests that the initial perovskite phases are better catalysts for the $\mathrm{ODH}$ reaction than the phases present after the catalyst decomposes.

XPS

Initial XPS analysis of the perovskites reveals the expected presence of $\mathrm{Ba}, \mathrm{Ce}, \mathrm{C}$ and $\mathrm{O}$ on the surface of the catalyst, as well as $\mathrm{Mg}$ or $\mathrm{Ca}$ for perovskites containing these modifiers. The $\mathrm{Ce} 3 \mathrm{~d} / \mathrm{Ba} 3 \mathrm{~d}_{5 / 2}$ intensity ratio, after correcting for relative sensitivity factors $[20,24]$, corresponds to the expected $\mathrm{Ba} / \mathrm{Ce}$ atomic ratio of $\sim 1.0$ for $\mathrm{BaCeO}_{3}$ and the Ca- and Mg-substituted materials. Upon subjecting each of these materials to thermal treatments in various reactive environments, the $\mathrm{Ce} 3 \mathrm{~d} / \mathrm{Ba} 3 \mathrm{~d}_{5 / 2}$ ratio invariably declines 
with increasing severity of the treatment, ultimately approaching zero following treatment in ethane $/ \mathrm{CO}_{2}$ mixtures at $700{ }^{\circ} \mathrm{C}$ (Figure 2). At this stage, both the $\mathrm{C} 1 \mathrm{~s}$ and $\mathrm{O}$ 1s XPS regions reveal the presence of substantial amounts of carbonate, and very little metal oxide. Two explanations can be advanced to account for these observations. First, upon decomposition of the perovskite structure into $\mathrm{BaCO}_{3}$ and $\mathrm{CeO}_{2}, \mathrm{BaCO}_{3}$ may preferentially segregate to the surface of the catalyst, thereby severely attenuating the $\mathrm{Ce}$ XPS signal. Second, the $\mathrm{BaCO}_{3}$ phase may be in the form of very small, highly dispersed particles, while the $\mathrm{CeO}_{2}$ particles are present as very large crystallites. As a result, very little $\mathrm{CeO}_{2}$ surface is present relative to the $\mathrm{BaCO}_{3}$ surface, and the surface sensitive XPS technique detects mainly $\mathrm{Ba}$. Regardless of the explanation, the catalyst surface following reaction at $700{ }^{\circ} \mathrm{C}$ clearly consists primarily of $\mathrm{BaCO}_{3}$.

XPS analysis of the Mg and $\mathrm{Ca}$ containing perovskites indicates that both additives are initially present on the surface in amounts that are close to or slightly below the expected stoichiometric values (Figure 3). Upon subjecting the $\mathrm{Ca}$ containing materials to increasingly severe reaction conditions, the $\mathrm{Ca} 2 \mathrm{p}$ signal decreases relative to the $\mathrm{Ba} 3 \mathrm{~d}_{5 / 2}$ signal, ultimately falling to a value approximately one third that expected for a uniform stoichiometric mixture, regardless of whether the Ca was initially on an A or B site. Thus, during decomposition of the perovskite structure, the $\mathrm{Ca}$ either becomes associated primarily with the $\mathrm{CeO}_{2}$ phase, which exposes very little surface area to the XPS probe (see above), or the $\mathrm{Ca}$ forms large $\mathrm{CaCO}_{3}$ particles which also expose very little surface area to the XPS probe. Given the absence of any evidence for a separate Ca containing phase from $\mathrm{XRD}$ analysis, the former explanation is most likely. This proposed inclusion 
of $\mathrm{Ca}$ into the $\mathrm{CeO}_{2}$ structure could disrupt the long range order of the $\mathrm{CeO}_{2}$ lattice and result in the broad peaks observed by XRD, even if the $\mathrm{CeO}_{2}$ particles are quite large.

Like the Ca containing perovskites, XPS analysis of the Mg containing perovskite initially shows a $\mathrm{Mg}$ surface content very near the bulk stoichiometric value. In contrast to the $\mathrm{Ca}$ containing perovskites, the $\mathrm{Mg}$ signal increases relative to the $\mathrm{Ba} 3 \mathrm{~d}_{5 / 2}$ signal as the perovskite is exposed to increasingly severe reaction conditions. Thus, $\mathrm{Mg}$ is apparently able to diffuse out of the perovskite lattice and spread across the surface of the catalyst particles. Ultimately, upon decomposition of the perovskite structure, the $\mathrm{Mg}$ signal returns to a value very close to stoichiometric. Thus, unlike $\mathrm{Ca}, \mathrm{Mg}$ appears to associate with the $\mathrm{BaCO}_{3}$ phase following decomposition, and appears to be uniformly distributed throughout the $\mathrm{BaCO}_{3}$ lattice.

As a final note on the XPS analysis, it should be mentioned that the Ce $3 \mathrm{~d}$ peak shapes prior to any treatments do not correspond to fully oxidized $\mathrm{Ce}^{4+}$. Instead the spectra indicate a mixture of $\mathrm{Ce}^{3+}$ and $\mathrm{Ce}^{4+}$. Upon heating in vacuum, the extent of oxidation of Ce generally increases, indicating that diffusion of oxygen from the bulk to the surface is occurring. During treatment in reactive environments, the Ce becomes more highly reduced, especially for treatments involving the lean ethane/oxygen mixture or pure ethane. Taken together these results are consistent with the expectation that these perovskite materials allow efficient oxygen transport, and that $\mathrm{Ce}$ undergoes facile redox chemistry under reaction conditions. 


\section{Conclusions}

Ba-Ce-O perovskite phases with $\mathrm{Ca}$ or $\mathrm{Y}$ partially substituted for cerium show activity for the complete oxidation of ethane at temperatures $\leq 650^{\circ} \mathrm{C}$. The behavior of the $\mathrm{Ba}-\mathrm{Ce}-\mathrm{O}$ family of materials at higher temperatures is complex. All the $\mathrm{Ba}-\mathrm{Ce}-\mathrm{O}$ materials tested are unstable under high temperature reaction conditions and eventually convert to a mixture of $\mathrm{BaCO}_{3}, \mathrm{CeO}_{2}$ and perhaps other phases. Characterization of the catalysts by XPS has found that at $700^{\circ} \mathrm{C}$, the majority of the working catalytic surface area consists of $\mathrm{BaCO}_{3}$. It is not known whether this is due to particle size effects or atom migration during reactions. When Ca-substituted materials decompose, the Ca most likely associates with the $\mathrm{CeO}_{2}$ phase, while for $\mathrm{Mg}$ substituted materials, the $\mathrm{Mg}$ most likely associates with the $\mathrm{BaCO}_{3}$ phase.

The fine powder $\mathrm{Ba}-(\mathrm{Ce}-\mathrm{Ca})-\mathrm{O}$ system showed relatively high selectivity to ethylene at temperatures of 700 and $750{ }^{\circ} \mathrm{C}$. However, a $750^{\circ} \mathrm{C}$ treatment reduced the selectivity in subsequent tests at $700^{\circ} \mathrm{C}$. The selectivity to ethylene over the granular $\mathrm{Ba}-\mathrm{Ce}-\mathrm{O}$ catalysts rapidly decreased during the first moments of reaction at $700{ }^{\circ} \mathrm{C}$. Thereafter the catalysts primarily produced $\mathrm{CO}_{2}$. These results suggest that the initial perovskite phase enhances the oxidative dehydrogenation reaction at temperatures of at least $700{ }^{\circ} \mathrm{C}$. In contrast, $\mathrm{BaO}_{2}$ formed when $\mathrm{BaPbO}_{3}$ and $\mathrm{BaBiO}_{3}$ decompose to $\mathrm{BaCO}_{3}$ and other phases has been suggested to be the active catalyst for the OCM reaction [6]. However, in the present case, one of the coproducts of the catalyst decomposition, $\mathrm{CeO}_{2}$, is a well known catalyst for the complete oxidation of hydrocarbons. 


\section{Acknowledgements}

This work was supported by the United States Department of Energy under contract DEAC04-94AL85000. Sandia is a multiprogram laboratory operated by Sandia Corporation, a Lockheed Martin Company, for the United States Department of Energy.

\section{References}

1. W.F. Libby, Science, 171, (1971) 499

2. H.M. Zhang, Y. Shimuzu, Y. Teraoka, N. Miura, N. Yamazoe, J. Catal. 121 (1990) 432.

3. T. Hayakawa, H Orita, M. Shimizu, K. Takehira, A.G. Andersen, K. Nomura, Y. Ujihira, Catal. Lett. 16 (1992) 359.

4. H. Nagamoto, K. Amanuma, H. Nobutomo, H. Inoue, Chem. Lett. (1988) 237.

5. Y. Inoue, H. Sano, Z. Sato, J. Mater. Sci. Lett. 8 (1989) 17.

6. D. Dissanayake, K.C.C. Kharas, J.H. Lunsford, M.P. Rosynek, J. Catal. 139 (1993) 652.

7. A.G. Andersen, T. Hayakawa, M. Shimuzu, K. Suzuki, K. Takehira, Catal. Lett. 23 (1994) 59.

8. K.I. Machida, M. Enyo, J. Chem. Soc., Chem. Commun. (1987) 1639.

9. O.J. Velle, A. Andersen, K.-J. Jens, Catal. Today 6 (1990) 567.

10. T. Hayakawa, A.G. Andersen, H. Orita, M. Shimizu, K. Takehira, Catal. Lett. 16 (1992) 373. 
11. G. Yi, T. Hayakawa, A.G. Andersen, K. Suzuki, S. Hamakawa, A.P.E. York, M.

Shimizu, K. Takehira, Catal. Lett. 38 (1996) 189.

12. E.M. Kennedy, N.W. Cant, Appl. Catal. 75 (1991) 321.

13. E.M. Kennedy, N.W. Cant, Appl. A 87 (1992) 171.

14. J.-L. Dubois, C.J. Cameron, Appl. Catal. 67 (1990) 49.

15. M.K. Paria, H.S. Maiti, Solid State Ionics 13 (1984) 285.

16. H. Iwahara, H. Uchida, K. Ono, K. Ogaki, J. Electrochem. Soc. 135 (1988) 530.

17. T.M. Nenoff, N.B. Jackson, J.E. Miller, A.G. Sault, D. Trudell, MRS Symposium Series Vol. 497, 1997.

18. A.G. Sault, E.P. Boespflug, C.H.F. Peden, J. Phys. Chem. 98 (1994) 1652.

19. A.G. Sault, J. Catal. 156 (1995) 154.

20. C.D. Wagner, H.A. Six, W.T. Jansen, J.A. Taylor, Appl. Surface Sci., 9 (1981) 203.

21. C.D. Wagner, W.M. Riggs, L.E. Davis, J.F. Moulder, G.E. Muilenberg, Handbook of X-ray Photoelectron Spectroscopy, Perkin-Elmer Corp., Eden Prairie, MN, 1979.

22. V. Longo, F. Ricciardiello, D. Minichelli, J. Mater. Chem. 16 (1981) 3503.

23. R. Burch, E.M. Crabb, Appl. Catal. A 97 (1993) 49.

24. C.D. Wagner, L.E. Davis, M.V. Zeller, J.A. Taylor, R.H. Raymond, L. H. Gale, Surface Int. Anal. 3 (1981) 211. 
Table 1. Selected results of reaction testing over $\mathrm{Ba}\left(\mathrm{Ce}_{1-\mathrm{y}} \mathrm{M}_{\mathrm{y}}\right) \mathrm{O}_{3-\delta}$ powders in low temperature regime.

\begin{tabular}{|c|c|c|c|c|c|c|}
\hline \multirow[t]{2}{*}{ Sample } & \multirow[t]{2}{*}{ Temp. $\left({ }^{\circ} \mathrm{C}\right)$} & \multicolumn{2}{|c|}{ Conversion $(\%)$} & \multicolumn{2}{|c|}{ Selectivity (\%) } & \multirow{2}{*}{$\begin{array}{c}\text { Yield }(\%) \\
\mathrm{C}_{2} \mathrm{H}_{4} \\
\end{array}$} \\
\hline & & $\mathrm{C}_{2} \mathrm{H}_{6}$ & $\mathrm{O}_{2}$ & $\mathrm{CO}_{2}$ & $\mathrm{C}_{2} \mathrm{H}_{4}$ & \\
\hline \multirow[t]{3}{*}{ Thermal } & 500 & 0.17 & 0.83 & 74 & 26 & 0.045 \\
\hline & 600 & 2.0 & 8.3 & 60 & 40 & 0.79 \\
\hline & 650 & 5.5 & 21 & 51 & 49 & 2.7 \\
\hline \multirow{3}{*}{$\mathrm{BaCeO}_{3}$} & 500 & 1.6 & 7.8 & 63 & 37 & 0.57 \\
\hline & 600 & 7.6 & 35 & 69 & 31 & 2.4 \\
\hline & 650 & 16 & 85 & 77 & 23 & 3.7 \\
\hline \multirow[t]{3}{*}{$\mathrm{Ba}\left(\mathrm{Ce}_{0.9} \mathrm{Ca}_{0.1}\right) \mathrm{O}_{2.9}$} & 500 & 3.0 & 17 & 91 & 9.4 & 0.28 \\
\hline & 600 & 13 & 85 & 96 & 4.2 & 0.55 \\
\hline & 650 & 15 & 96 & 95 & 5.3 & 0.81 \\
\hline \multirow{3}{*}{$\mathrm{Ba}\left(\mathrm{Ce}_{0.9} \mathrm{Y}_{0.1}\right) \mathrm{O}_{2.95}$} & 500 & 2.5 & 16 & 99 & 0.025 & 0.006 \\
\hline & 600 & 12 & 76 & 95 & 4.8 & 0.57 \\
\hline & 650 & 15 & 93 & 93 & 6.4 & 0.94 \\
\hline \multirow[t]{3}{*}{$\mathrm{Ba}\left(\mathrm{Ce}_{0.9} \mathrm{La}_{0.1}\right) \mathrm{O}_{2.95}$} & 500 & 2.3 & 11 & 69 & 31 & 0.73 \\
\hline & 600 & 7.9 & 43 & 81 & 18 & 1.4 \\
\hline & 650 & 12 & 68 & 81 & 16 & 2.0 \\
\hline \multirow[t]{3}{*}{$\mathrm{Ba}\left(\mathrm{Ce}_{0.9} \mathrm{Nd}_{0.1}\right) \mathrm{O}_{2.95}$} & 500 & 1.3 & 7.6 & 86 & 14 & 0.19 \\
\hline & 600 & 7.0 & 39 & 84 & 16 & 1.1 \\
\hline & 650 & 22 & $>99$ & 64 & 31 & 6.8 \\
\hline
\end{tabular}


Table 2. Results of reaction testing over $\mathrm{Ba}\left(\mathrm{Ce}_{1-y} \mathrm{Ca}_{y}\right) \mathrm{O}_{3-\delta}$ powders in low temperature regime.

\begin{tabular}{|c|c|c|c|c|}
\hline Sample & $\begin{array}{c}\text { Temperature } \\
\left({ }^{\circ} \mathrm{C}\right)\end{array}$ & $\begin{array}{c}\mathrm{C}_{2} \mathrm{H}_{6} \text { Conversion } \\
(\%)\end{array}$ & $\begin{array}{c}\mathrm{C}_{2} \mathrm{H}_{4} \text { Selectivity } \\
(\%)\end{array}$ & $\begin{array}{c}\mathrm{C}_{2} \mathrm{H}_{4} \text { Yield } \\
(\%)\end{array}$ \\
\hline \multirow{5}{*}{$\mathrm{Ba}\left(\mathrm{Ce}_{0.95} \mathrm{Ca}_{0.05}\right) \mathrm{O}_{2.95}$} & 350 & 1.0 & 19 & 0.19 \\
\hline & 400 & N.M.* & N.M. & N.M. \\
\hline & 450 & 3.5 & 6.8 & 0.24 \\
\hline & 500 & N.M. & N.M. & N.M. \\
\hline & 550 & 13 & 0.71 & 0.092 \\
\hline \multirow[t]{2}{*}{1} & 600 & 15 & 0.63 & 0.095 \\
\hline & 650 & 15 & 1.6 & 0.24 \\
\hline \multirow[t]{7}{*}{$\mathrm{Ba}\left(\mathrm{Ce}_{0.9} \mathrm{Ca}_{0.1}\right) \mathrm{O}_{2.90}$} & 350 & 0.0 & 0.0 & 0.0 \\
\hline & 400 & 0.39 & 12 & 0.16 \\
\hline & 450 & 0.85 & 18 & 0.15 \\
\hline & 500 & 3.0 & 9.4 & 0.28 \\
\hline & 550 & 10 & 3.0 & 0.30 \\
\hline & 600 & 13 & 4.2 & 0.55 \\
\hline & 650 & 15 & 5.3 & 0.80 \\
\hline \multirow{7}{*}{$\mathrm{Ba}\left(\mathrm{Ce}_{0.85} \mathrm{Ca}_{0.15}\right) \mathrm{O}_{2.85}$} & 350 & 0.0 & 0.0 & 0.0 \\
\hline & 400 & 0.25 & 13 & 0.033 \\
\hline & 450 & 2.0 & 18 & 0.36 \\
\hline & 500 & 3.8 & 16 & 0.61 \\
\hline & 550 & 8.3 & 12 & 1.0 \\
\hline & 600 & 14 & 12 & 1.68 \\
\hline & 650 & 13 & 5.0 & 0.65 \\
\hline \multirow[t]{7}{*}{$\mathrm{Ba}\left(\mathrm{Ce}_{0.80} \mathrm{Ca}_{0.20}\right) \mathrm{O}_{2.80}$} & 350 & 0.0 & 0.0 & 0.0 \\
\hline & 400 & 0.10 & 13 & 0.013 \\
\hline & 450 & 0.45 & 16 & 0.072 \\
\hline & 500 & 1.3 & 19 & 0.25 \\
\hline & 550 & 4.0 & 20 & 0.80 \\
\hline & 600 & 17 & 32 & 5.4 \\
\hline & 650 & 18 & 23 & 4.1 \\
\hline \multirow[t]{7}{*}{$\mathrm{BaCeO}_{3}$} & 350 & 0.0 & 0.0 & 0.0 \\
\hline & 400 & 0.0 & 0.0 & 0.0 \\
\hline & 450 & 0.57 & 38 & 0.22 \\
\hline & 500 & 1.6 & 37 & 0.59 \\
\hline & 550 & 4.2 & 33 & 1.4 \\
\hline & 600 & 7.6 & 31 & 2.4 \\
\hline & 650 & 16 & 23 & 3.7 \\
\hline
\end{tabular}

*Not measured 
Table 3. Results of reaction testing over $\mathrm{Ba}\left(\mathrm{Ce}_{1-y} \mathrm{M}_{\mathrm{y}}\right) \mathrm{O}_{3-\delta}$ powders in high temperature regime.

\begin{tabular}{ccccccc} 
Sample & Temp. $\left({ }^{\circ} \mathrm{C}\right)$ & \multicolumn{2}{c}{ Conversion $(\%)$} & \multicolumn{2}{c}{ Selectivity $(\%)$} & Yield (\%) \\
& & $\mathrm{C}_{2} \mathrm{H}_{6}$ & $\mathrm{O}_{2}$ & $\mathrm{CO}_{2}$ & $\mathrm{C}_{2} \mathrm{H}_{4}$ & $\mathrm{C}_{2} \mathrm{H}_{4}$ \\
\hline Thermal & 700 & 31 & $>99$ & 40 & 56 & 17 \\
& 750 & 39 & $>99$ & 30 & 61 & 24 \\
$\mathrm{BaCeO}_{3}$ & 700 & 31 & $>99$ & 41 & 52 & 16 \\
& 750 & 49 & $>99$ & 21 & 56 & 28 \\
$\mathrm{Ba}\left(\mathrm{Ce}_{0.9} \mathrm{Ca}_{0.1}\right) \mathrm{O}_{2.9}$ & 700 & 53 & $>99$ & 20 & 64 & 34 \\
& 750 & 60 & $>99$ & 17 & 59 & 35 \\
$\mathrm{Ba}\left(\mathrm{Ce}_{0.9} \mathrm{Y}_{0.1}\right) \mathrm{O}_{2.95}$ & 700 & 16 & $>99$ & 89 & 7.2 & 1.2 \\
& 750 & 21 & $>99$ & 64 & 11 & 2.3 \\
$\mathrm{Ba}\left(\mathrm{Ce}_{0.9} \mathrm{La}_{0.1}\right) \mathrm{O}_{2.95}$ & 700 & 33 & $>99$ & 36 & 48 & 16 \\
& 750 & 50 & $>99$ & 19 & 48 & 24 \\
$\mathrm{Ba}\left(\mathrm{Ce}_{0.9} \mathrm{Nd}_{0.1}\right) \mathrm{O}_{2.95}$ & 700 & 39 & $>99$ & 31 & 54 & 21 \\
& 750 & 55 & $>99$ & 20 & 57 & 31 \\
& & & & & \\
& & & & & & \\
& & & & & & \\
\end{tabular}


Figure 1. The selectivity of granular perovskite catalysts (all compositions $\bullet$ ) compared to the thermal noncatalytic reaction ( $\square$ ) as a function of conversion. The large number of data points results from changes in the catalysts with time on stream.

Figure 2: Variation in $\mathrm{Ce} 3 \mathrm{~d} / \mathrm{Ba} 3 \mathrm{~d}_{5 / 2}$ XPS ratio as a function of treatment conditions for $\mathrm{BaCeO}_{3}(\bullet), \mathrm{Ba}\left(\mathrm{Ce}_{0.8} \mathrm{Ca}_{0.2}\right) \mathrm{O}_{2.8}(\boldsymbol{\nabla}),\left(\mathrm{Ba}_{0.8} \mathrm{Ca}_{0.2}\right) \mathrm{CeO}_{3}(\boldsymbol{\Delta})$, and $\left(\mathrm{Ba}_{0.8} \mathrm{Mg}_{0.2}\right) \mathrm{CeO}_{3}(\boldsymbol{\nabla})$. The ratios measured for the as-prepared materials are all very close to the value expected for a stoichiometric (1:1) mixture of $\mathrm{Ce}$ and $\mathrm{Ba}$.

Figure 3: Variation in $\mathrm{Ca} 2 \mathrm{p} / \mathrm{Ba} 3 \mathrm{~d}_{5 / 2}$ and $\mathrm{Mg} 2 \mathrm{p} / \mathrm{Ba} 3 \mathrm{~d}_{5 / 2}$ ratios as a function of treatment conditions for $\mathrm{Ba}\left(\mathrm{Ce}_{0.8} \mathrm{Ca}_{0.2}\right) \mathrm{O}_{2.8}(\mathbf{m}),\left(\mathrm{Ba}_{0.8} \mathrm{Ca}_{0.2}\right) \mathrm{CeO}_{3}(\boldsymbol{\Delta})$, and $\left(\mathrm{Ba}_{0.8} \mathrm{Mg}_{0.2}\right) \mathrm{CeO}_{3}(\boldsymbol{\nabla})$. The ratios expected for if the $\mathrm{Ca}$ or $\mathrm{Mg}$ were uniformly distributed throughout the catalyst matrix are shown by the dashed lines. 


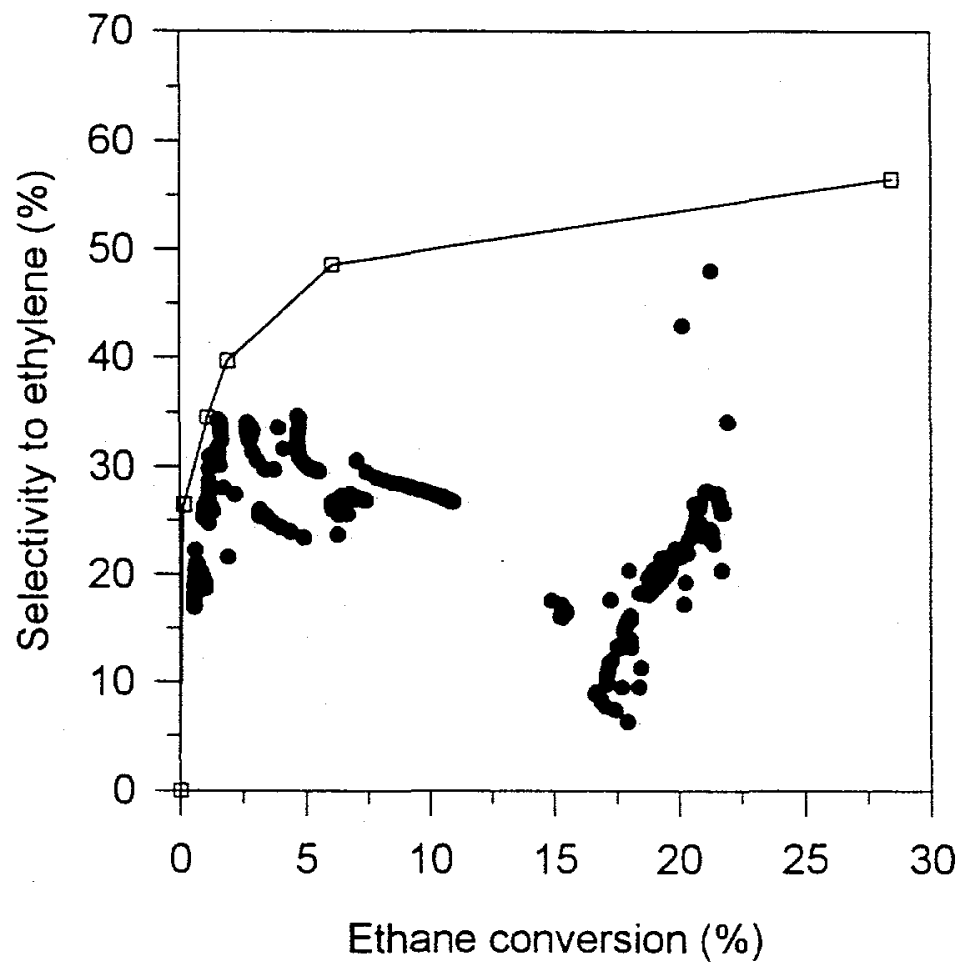




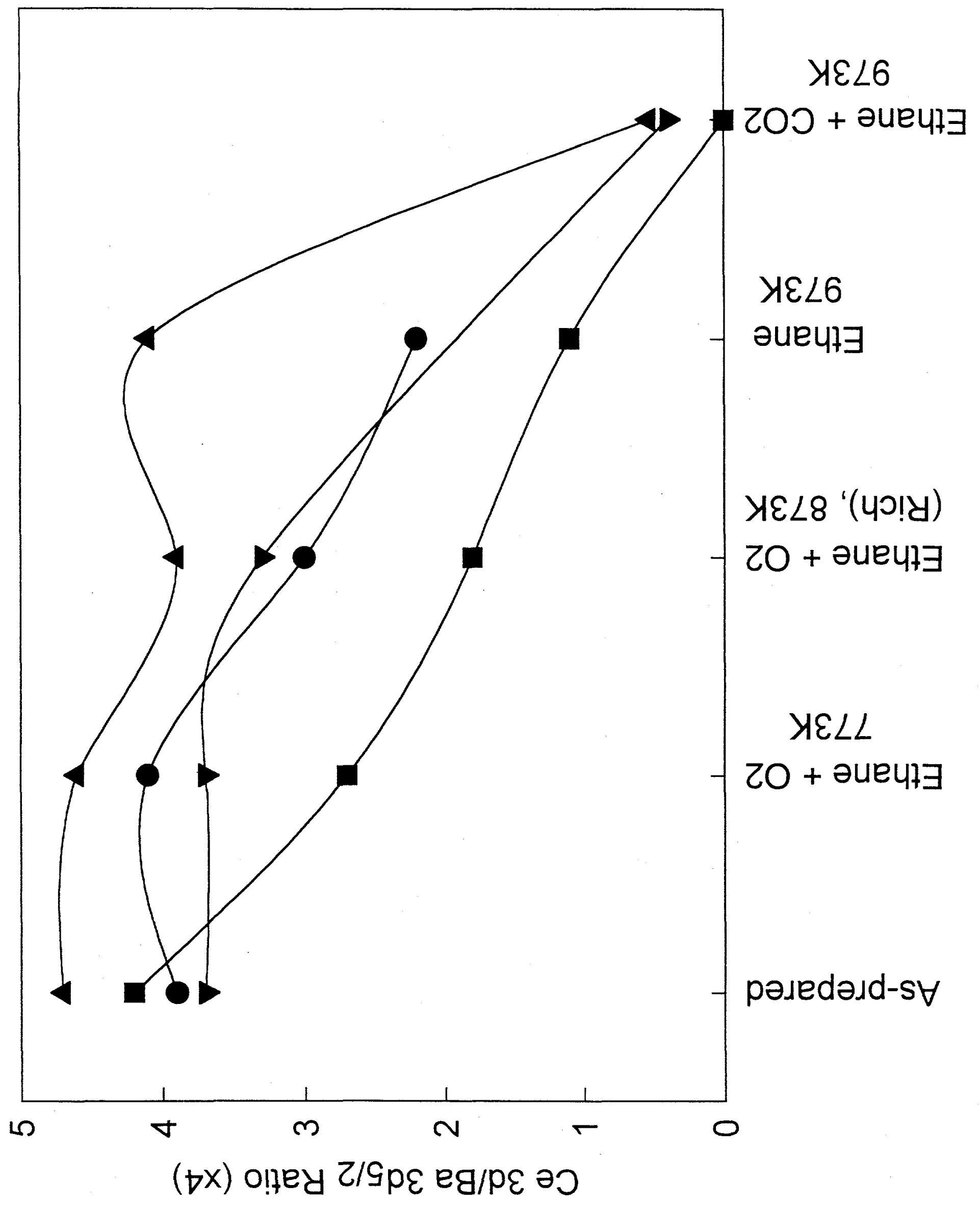




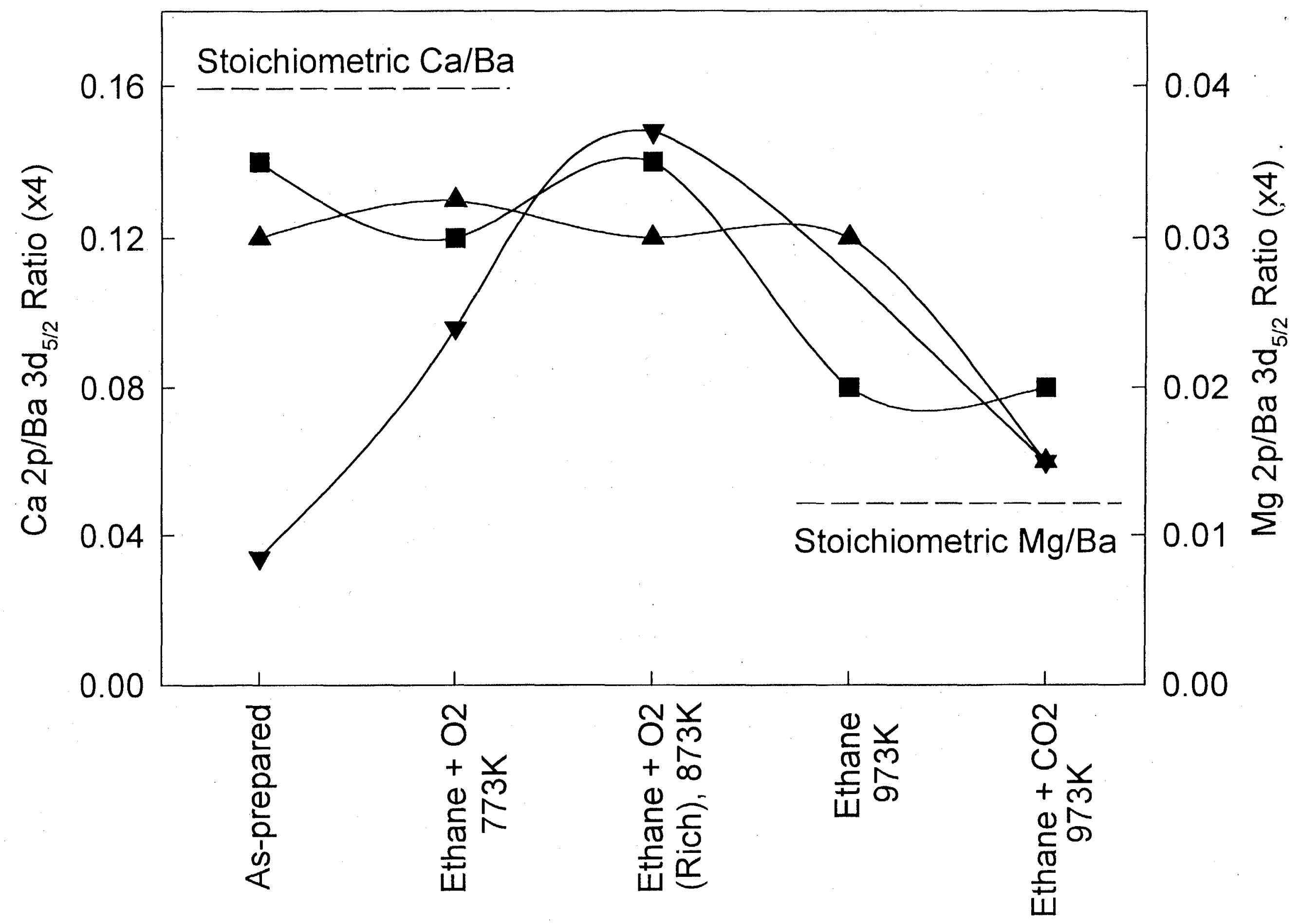

